\title{
Pengaruh Model Pembelajaran Kooperatif Tipe Makea Match Terhadap Motivasi Siswa Pada Konsep Sistem Gerak Pada Manusia Di SMA Negeri 1 Bandar Baru
}

\author{
Ervina Dewi, S.Si., M.Pd ${ }^{1}$, Muhajirin, S.Pd ${ }^{2}$ \\ ${ }^{1.2}$ Prodi Pendidikan Biologi Fakultas Keguruan dan Ilmu Pendidikan Universitas Jabal Ghafur
}

\begin{abstract}
Abstrak
Penelitian ini bertujuan untuk mengetahui Pengaruh Model Pembelajaran Kooperatif Tipe Make a match Terhadap Motivasi siswa Pada Materi Sistem gerak pada manusia di SMA N 1 Bandar Baru. Populasi dalam penelitian ini adalah siswa kelas XI IPA SMA Negeri 1 Bandar Baru tahun ajaran 2016/2017 yang berjumlah 150 siswa. Sampel sebanyak 50 siswa yang dibagi menjadi dua kelas yaitu kelas eksperimen (Penerapan Make a match) sebanyak 25 siswa, dan kelas kontrol (Tanpa (Penerapan Make a match) sebanyak 25 siswa. Metode yang digunakan adalah pendekatan kuantitatif. Pengumpulan data dilakukan dengan angket model Rating Scale dan hasil penelitian dianalisis secara deskriptif (persentase). Hasil penelitian menunjukkan bahwa siswa pada ke dua kelas perlakuan memiliki motivasi belajar yang berkategori ' baik' untuk setiap indikator yang dinilai (78,775 \% untuk kelas eksperimen dan 76,975\% untuk kelas kontrol). Peningkatan motivasi belajar pada kelas dengan penerapan Make A Match hanya sebesar 0,02 (1,8 point) dibandingkan dengan kelas kontrol untuk ke delapan indikator yang dinilai.
\end{abstract}

Kata Kunci : Model pembelajaran kooperatif tipe Make a Match, Motivasi siswa, Sistem gerak pada manusia.

\section{PENDAHULUAN}

Kegiatan pembelajaran di sekolah merupakan kegiatan utama dalam proses pendidikan pada umumnya yang bertujuan membawa anak didik atau siswa menuju pada keadaan yang lebih baik. Keberhasilan suatu proses pembelajaran dari ketercapaian siswa dalam mengikuti kegiatan pembelajaran. Keberhasilan yang dimaksud dapat diamati dari dua sisi yaitu dari tingkat pemahaman dan penguasaan materi yang diberikan oleh guru (Sudjana, 2001).

Keberhasilan sebuah pembelajaran juga sangat ditentukan oleh guru yang mengajar di suatu kelas. Seorang guru yang profesional ditandai dengan sejauh mana guru tersebut mampu menguasai kelas yang diasuhnya, dan mengantarkan peserta didiknya mencapai hasil belajar yang optimal. Dalam hal ini, guru harus merancanakan sebuah kegiatan pembelajaran secara sistematis dan berpedoman pada seperangkat aturan dan merencanakan tentang pendidikan yang dikemas dalam bentuk kurikulum.

Salah satu upaya untuk meningkatkan motivasi dan keberhasilan belajar siswa, yaitu dengan menggunakan pembelajaran aktif di mana siswa melakukan sebagian besar pekerjaan yang harus dilakukan. Belajar aktif merupakan langkah cepat, menyenangkan, mendukung dan menarik hati dalam belajar untuk mempelajari sesuatu dengan baik. Belajar aktif membantu untuk mendengar, melihat, mengajukan pertanyaan tentang pelajaran tertentu dan mendiskusikannya dengan yang lain. Dalam belajar aktif yang paling penting bagi siswa perlu memecahkan masalah sendiri, menemukan contohcontoh, mencoba keterampilan-keterampilan dan mengerjakan tugas-tugas yang tergantung pada pengetahuan yang telah mereka miliki atau yang akan dicapai.
Berdasarkan hasil observasi yang dilakukan di SMA Negeri 1 Bandar Baru, proses pembelajaran sistem gerak pada manusia masih menggunakan metode konvensional (metode ceramah), yaitu guru yang cenderung lebih aktif, sedangkan siswanya cenderung lebih pasif. Siswa tidak termotivasi untuk belajar sehingga siswa kurang memahami setiap materi yang diajarkan.

Dalam melaksanakan proses belajar mengajar diperlukan langkah-langkah sistematis untuk mencapai tujuan yang telah ditentukan. Hal yang harus dilakukan dengan menggunakan metode yang cocok dengan kondisi siswa agar siswa dapat berpikir kritis, logis, dan dapat memecahkan masalah dengan sikap terbuka, kreatif, dan inovatif dan menjadikan siswa termotivasi. Dalam pembelajaran dikenal berbagai model pembelajaran Make a Match.

Menurut Rusman (2011: 223-233) Model Make A Match (membuat pasangan) merupakan salah satu jenis dari metode dalam pembelajaran kooperatif. Metode ini dikembangkan oleh Curran (1994). Salah satu cara keunggulan teknik ini adalah peserta didik mencari pasangan sambil belajar mengenai suatu konsep atau topik, dalam suasana yang menyenangkan.

Penerapan pendekatan ini dimulai dari teknik yaitu siswa disuruh mencari pasangan kartu yang merupakan jawaban atau soal sebelum batas waktunya, siswa yang dapat mencocokkan kartunya diberi poin (Ali, 2010:31).

Pada model pembelajaran kooperatif tipe Make A Match terlebih dahulu diadakan latihan kerjasama kelompok. Hal ini bertujuan untuk mengenal dan memahami karakteristik masingmasing individu dan kelompok. Berdasarkan uraian diatas, dapat dipahami bahwa; (1) model pembelajaran kooperatif tipe Make A Match 
bertujuan untuk menumbuhkan sikap saling menghormati, menumbuhkan sikap tanggung jawab, meningkatkan percaya diri dalam menyelesaikan suatu masalah, (2) merupakan model pembelajaran yang menuntut anak didik aktif dalam pembelajaran, keterampilan-keterampilan mulai dari tingkat awal maupun tingkat mahir yang dimiliki anak didik akan terlihat dalam pembelajaran ini, (3) lingkungan dalam pembelajaran Make A Match diusahakan demokratis, anak didik diberi kebebasan untuk mengutarakan pendapat (Djumiati, 2010).

Hasil penelitian sebelumnya telah membuktikan bahwa penerapan model pembelajaran kooperatif tipe Make A Match mampu meningkatkan motivasi belajar siswa dan hasil belajar PKN Pada siswa kelas VIIC SMP Negeri 1 Ngawen Kabupaten Blora Tahun 2008/2009( Riyanto, 2009). Berdasarkan uraian diatas, maka penelitian ini sangat perlu untuk dilaksanankan guna menetahui pengaruhnya terhadap motivasi belajar siswa pada mata pelajaran Biologi.

\section{METODOLOGI}

\section{Pendekatan dan Jenis Penelitian}

Penelitian ini dilakukan dengan menggunakan pendekatan kuantitatif dengan jenis penelitian eksperimen. Penelitian ini menggunakan dua kelas yaitu kelas eksperimen dan kelas kontrol.

\section{Populasi dan Sampel Penelitian}

Populasi dalam penelitian ini adalah siswa kelas XI IPA SMA Negeri 1 Bandar Baru yang terdiri dari 6 kelas dengan jumlah 150 siswa. Penetuan sampel di lakukan dengan cara Random Sampling (dengan cara acak), sedangkan yang di jadikan sampelnya adalah 2 kelas yaitu kelas XI IPA 1 dijadikan kelas kontrol (Tanpa penerapan Make a match) dan XI IPA II dijadikan kelas eksperimen (penerapan Make a match) dengan jumlah 25 siswa per kelas.

\section{Tehnik pengumpulan data}

Data yang dikumpulkan berupa data motivasi siswa dilakukan melalui pemberian angket. Riduwan (2010:71) menyatakan bahwa angket adalah daftar pertanyaan yang diberikan kepada orang lain bersedia menerima respons (responden) sesuai dengan permintaan pengguna.

Angket ini dibuat berupa model skala likert yang terdiri dari lima jawaban alternatif, yakni Sangat Setuju (SS), Setuju (S), Tidak Setuju (TS), Sangat Tidak Setuju (STS) setiap butir dalam kuisioner diberi skor dari angka 5-4-3-2-1 bila pernyataan dalam angket bersifat positif, dan pernyataan bersifat negatif masing-masing butir memiliki skor dari 1-2-3-4. (Sundayana, 2014 : 9).

Angket ini terdiri dari delapan kategori dan pertanyaan angket bersifat positif dan negatif. Instrumen disusun melalui langkah-langkah sebagai berikut: (a) Membuat kisi-kisi kuesioner berdasarkan variabel yang diteliti, (b) Menyusun butir pernyataan sesuai dengan kisi-kisi yang telah dibuat, (c) Mendiskusikan dan berkonsultasi dengan dosen pembimbing untuk memperoleh kesahihan konstruk butir, dan (d) melaksanakan uji coba instrumen.

\section{Parameter}

Parameter pada penelitian ini adalah motivasi siswa.

\section{Teknik Analisis Data}

Data hasil penelitian dianalisis secara deskriftif berupa persentase dan disajikan dalam bentuk tabel.

\section{HASIL DAN PEMBAHASAN}

Data motivasi siswa diperoleh melalui pengisian angket motivasi siswa yang terdiri dari 8 indikator. Data motivasi siswa dapat dilihat pada Tabel 1.

Tabel 1 Motivasi Siswa

\begin{tabular}{|c|c|c|c|c|c|}
\hline \multirow[b]{2}{*}{$\begin{array}{l}\mathbf{N} \\
\mathbf{o}\end{array}$} & \multirow[b]{2}{*}{ Indikator } & \multicolumn{2}{|c|}{ Pernyataan } & \multicolumn{2}{|c|}{ Kelas } \\
\hline & & positif & $\underset{f}{\text { negati }}$ & $\begin{array}{c}\text { eksperime } \\
\text { n \% }\end{array}$ & $\begin{array}{c}\text { kontro } \\
1 \%\end{array}$ \\
\hline 1 & $\begin{array}{l}\text { Tekun dalam } \\
\text { menghadapi } \\
\text { tugas }\end{array}$ & $1,2,4$ & 3,5 & 85,6 & 83 \\
\hline 2 & $\begin{array}{l}\text { Ulet dalam } \\
\text { menghadapi } \\
\text { kesulitan }\end{array}$ & $6,8,10$ & 7,9 & 85,2 & 82,8 \\
\hline 3 & $\begin{array}{l}\text { Menunjukkan } \\
\text { minat }\end{array}$ & $11,13,15$ & 12,14 & 81,8 & 80,8 \\
\hline 4 & $\begin{array}{l}\text { Senang bekerja } \\
\text { mandiri }\end{array}$ & $\begin{array}{c}16,17,18,1 \\
9\end{array}$ & 20 & 78,8 & 77,2 \\
\hline 5 & $\begin{array}{l}\text { Cepat bosan } \\
\text { pada tugas } \\
\text { tugas rutin }\end{array}$ & $21,23,24$ & 22,25 & 77 & 71,6 \\
\hline 6 & $\begin{array}{l}\text { Dapat } \\
\text { mempertahanka } \\
\mathrm{n} \text { pendapatnya }\end{array}$ & $26,27,29$ & 28,3 & 77,2 & 76,4 \\
\hline 7 & $\begin{array}{l}\text { Tidak mudah } \\
\text { melepaskan hal } \\
\text { yang di yakini } \\
\text { itu }\end{array}$ & $31,34,35$ & 32,33 & 72,6 & 72,4 \\
\hline 8 & $\begin{array}{l}\text { Senang mencari } \\
\text { dan } \\
\text { memecahkan } \\
\text { masalah soal } \\
\text { soal }\end{array}$ & $\begin{array}{c}36,37,38,3 \\
9\end{array}$ & 40 & 72 & 71,6 \\
\hline \multicolumn{4}{|c|}{ Rata-Rata } & 78,775 & 76,975 \\
\hline & Kat & & & Baik & Baik \\
\hline
\end{tabular}

Hasil penelitian terhadap pengaruh model pembelajaran Make A Match pada konsep Sistem gerak pada manusia di SMA 1 Bandar Baru dapat dilihat pada Tabel 1. Berdasarkan Tabel 1, nilai ratarata motivasi siswa untuk kedua kelas baik kelas eksperimen dan kontrol menunjukkan sebaran nilai motivasi yang berkategori baik untuk setiap indikator yang dinilai.

Tabel 1. menunjukkan bahwa penerpan model Make A Match mampu meningkatkan motivasi belajar siswa dibandingkan dengan kelas kontrol (tanpa penerapan Make A Match) walaupun masih dalam kategori yang sama untuk kedua kelas. 78,775 $\%$ untuk kelas dengan penerapan Make A Match dan $76,975 \%$ untuk kelas tanpa penerapan Make $A$ Match. Peningkatan motivasi belajar pada kelas 
dengan penerapan Make A Match hanya sebesar 0,02 (1,8 point) dibandingkan dengan kelas kontrol untuk kedelapan indikator yang diniliai. Hasil penelitian ini sesuai dengan hasil penelitian Mikran, dkk (2013) dan Saparwadi (2015) yaitu pemberian kartu yang berisikan soal/jawaban membantu siswa untuk memahami kembali materi yang di ajarkan dan memotivasi siswa dalam belajar.

Hasil penelitian menunjukkan bahwa siswa pada kedua kelas perlakuan memiliki motivasi belajar yang berkategori' baik ' untuk setiap indikator yang dinilai.

Motivasi ini terbentuk karena kesadaran diri atas pemahaman betapa pentingnya belajar untuk mengembangkan dirinya dan bekal untuk menjalani kehidupan. Hamalik (2011:161) menjelaskan bahwa motivasi adalah perubahan energi dalam diri seseorang yang ditandai dengan timbulnya perasaan dan reaksi untuk mencapai tujuan. Motivasi dapat berfungsi sebagai pengarah untuk mencapai tujuan dan berfungsi juga sebagai mesin penggerak dalam proses pencapaian tujuan. Sagala (2010: 104) juga telah menjelaskan bahwa motivasi adalah syarat mutlak dalam belajar. Motivasi sangat besar pengaruhnya pada proses belajar siswa. Tanpa adanya motivasi, maka proses belajar siswa tidak berjalan secara lancar. Seseorang akan belajar jika pada dirinya ada keinginan untuk belajar.

Peningkatan motivasi pada kelas pembelajaran dengan penerapan model Make A Match lebih menarik karena dilakukan secara berkelompok. Siswa terlihat lebih antusias untuk mencocokkan antara pertanyaan dan jawabannya sehingga pembelajarannya menjadi lebih bermakna.Menurut Syarif (2012), siswa yang memiliki motivasi belajar tinggi, maka seluruh proses pembelajaran akan diikuti dengan baik mulai dari rasa ingin tahu, intensitas dalam memperhatikan penjelasan pelajaran, membaca materi sampai pada mencari strategi yang paling tepat guna meraih prestasi akademik yang tinggi bagi dirinya. Selain itu Slavin (2009: 106) berpendapat bahwa siswa yang termotivasi akan dengan mudah diarahkan, diberi penugasan, cenderung memiliki rasa ingin tahu yang besar, aktif dalam mencari informasi tentang materi yang dijelaskan oleh guru serta menggunakan proses kognitif yang lebih tinggi untuk mempelajari dan menyerap pelajaran yang diberikan.

\section{KESIMPULAN}

Penerapan model pembelajaran kooperatif tipe Make A Match tidak mempengaruhi motivasi siswa pada konsep sistem gerak pada manusia di SMA Negeri 1 Bandar Baru. Hasil motivasi siswa pada kelas kontrol dan eksperimen berkategori "Baik".

\section{REFERENSI}

Ali, Hamdah. 2010. Peningkatan Hasil Belajar Biologi Siswa Melalui Penggunaan Model
Pembelajaran Kooperatif Make A Match Pada Konsep Reproduksi Manusia Di Kelas IX B SMP Negeri 2 Pangsid (The Improvement of The Students' Biology Learning Result Through The Application of Make A Match Cooperative Learning Model on Human Reproduction Concept At IX B Class SMP Negeri 2 Pangsid).Bionature Vol. 11 (1): Hlm: 29 - 36, April 2010 ISSN: 14114720. Halaman: 29-36. Diakses tanggal 23 Juli 2016.

Curran, L., 1994. Metode Pembelajaran Make A Match. Jakarta : Pustaka Belajar.

Djumiati, 2010. Peningkatan Kualitas Pembelajaran Pkn Melalui Model Pembelajaran Kooperatif Tipe Make A Match Di Kelas Vi Sdn Banyumanik 03 Semarang. Under Graduates thesis, Universitas Negeri Semarang.

Hamalik, Oemar. (2011). Proses Belajar Mengajar. Jakarta: Bumi Aksara.

Mikran,dkk. 2013. Penerapan Model Pembelajaran Make a Match untuk Meningkatkan Hasil Belajar Siswa Kelas VIIA SMP Negeri 1 Tomini Pada Konsep Gerak. Jurnal Pendidikan Fisika Tadulako ISSN 2338 3240. Sulawesi Tengah. FMIPA Tadulako

Riduwan dan Akdon. (2010). Rumus dan Data dalam Analisis Data Statistika. Bandung: Alfabeta.

Rusman. (2010). Model-model Pembelajaran: Mengembangkan Profesionalisme Guru. Jakarta: Rajawali Pers.

Sagala, Syaiful. (2010). Konsep dan Makna Pembelajaran. Bandung: Alfabeta.

Saparwadi, L., 2015. Penaruh Cooperative Learning Tipe Make A Match Terhadap Motivasi dan Hasil Belajar Matematika Siswa. BetaJurnal Matematika Indonesia. Vol 8 (1).

Slavin, Robert E., 2009. Cooperative Learning (Teori, Riset, Praktik). Bandung : Nusa Media.

Sudjana,N. 2001. Penilaian Hasil Proses Belajar Mengajar. Bandung: Remaja Rosdakarya.

Sundayana, R. 2014. Statistik Penelitian Pendidikan. Bandung; Penerbit Alfabet.

Syarif, Izzudin (2012) Pengaruh Penerapan Model Blended Learning terhadap Motivasi dan 
Prestasi Belajar Siswa SMKN 1 Paringin. S2 thesis, UNY. 